\section{Breaking Bad: Native Aquatic Plants Gone Rogue and the Invasive Species That Inspire Them}

\author{
Lyn A. Gettys ${ }^{1}$
}

ADDITIONAL INDEX WORDs. aggressive growth, alien species, exotic plants, introduced species, invasive species, monocultures, weedy plants

SUMMARY. Conventional wisdom suggests that native aquatic plants have evolved to fill a specific ecological niche, and that their growth is regulated by environmental conditions or the presence of natural enemies that limit the distribution or abundance of the species. However, it is becoming obvious that native species are not always well-behaved and can develop populations that quickly reach nuisance levels that require management to avoid negative ecological impacts. This work summarizes information presented at the American Society for Horticultural Science Invasive Plants Research Professional Interest Group Workshops in 2017 and 2018 , and it highlights the phenomenon of species that are considered both native and invasive in the aquatic ecosystems of Florida. These "natives gone rogue" are compared with the introduced species they mimic, and the consequences of excessive aquatic plant growth, regardless of the origin of the species, are described.

$\mathrm{N}$ on-native invasive species pose a significant threat to aquatic ecosystems and can disrupt the use of invaded systems. For example, alien plants often outcompete indigenous flora and form monocultures that cannot be used by native fauna, which require a diverse habitat to thrive (Dibble et al., 1996; Jeppesen et al., 1998; Madsen, 2014). In addition to reducing the richness of the species, invasive species can modify ecosystem services. Aggressive growth of alien species can change soil texture and deplete substrate nutrient reservoirs, resulting in insufficient resource availability

Received for publication 25 Feb. 2019. Accepted for publication 28 Mar. 2019

Published online 22 August 2019.

${ }^{1}$ University of Florida IFAS Fort Lauderdale Research and Education Center, 3205 College Avenue, Davie, FL 33314

This research was supported by the Florida Agricultural Experiment Station and by the U.S. Department of Agriculture National Institute of Food and Agriculture (HATCH project FLA-FTL-005682).

Special thanks to William Haller and James Leary for their critical reviews of this manuscript.

This paper was part of the Invasive Plants Research Professional Interest Group workshops "Strategies for Mitigating Invasiveness of Native Species," held on 30 Sept. 2017, in Waikoloa, HI, and "It's Native. Wait! It's Exotic...Oh No, It's a Nuisance!” held on 3 Aug. 2018 , in Washington, DC

L.A.G. is the corresponding author. E-mail: lgettys@ ufl.edu.

This is an open access article distributed under the CC BY-NC-ND license (https://creativecommons.org/ licenses/by-nc-nd $/ 4.0 /)$.

https://doi.org/10.21273/HORTTECH04333-19 for native flora (Madsen, 2014). Exotic trees may produce dense canopies that reduce the amount of light available for photosynthesis by understory plants. A similar situation occurs in aquatic ecosystems; rapid growth and expansion by floating [e.g., waterhyacinth (Eichhornia crassipes)], floatingleaved [e.g., crested floatingheart (Nymphoides cristata)], and canopyforming submersed [e.g., hydrilla (Hydrilla verticillata)] introduced species can interfere with the air-water interface, thereby blocking light, reducing oxygen in the water column, and degrading the habitat for native flora and fauna (Madsen, 2014).

Dense growth of exotic plants can interfere with anthropocentric interests. Terrestrial weeds can reduce crop yields by diverting water, nutrients, and other resources from cultivated plants and cause power outages and flooding (Bridges, 1994; Duryea and Kampf, 2017). Excessive growth of terrestrial invaders can exacerbate wildfires (Brooks et al., 2004). Fastgrowing weedy trees in Florida and other hurricane-prone regions may be ill-suited for heavy rains and high winds; ultimately, they may become projectiles, damage power lines, or crush residential and commercial properties (Duryea and Kampf, 2017).

Aquatic ecosystems are not immune to the hazards posed by invasive species. In fact, some argue that the problems associated with the introduction of exotic plants are more pronounced in these unique ecosystems. Crop production is somewhat uncommon in aquatic areas, but yields of aquatic food crops can be greatly reduced when invasive species are present. Weed pressure is considered a major limiting factor for rice (Oryza sativa) production, with losses that range from 10 to $100 \%$ in the absence of weed management efforts (Rao et al., 2007). Similar to terrestrial weeds, aquatic invaders pose risks to human health by creating a drowning hazard and serving as a habitat for undesirable insects [e.g., mosquitoes (Anopheles sp., Aedes sp. Culex sp., Mansonia sp., and others)] that vector human disease (Cuda, 2014). Aquatic weeds can impact human uses of waterbodies by disrupting hydropower operations, clogging irrigation intakes, blocking access to recreational resources, interfering with the use of watercraft, and reducing aesthetics (and property values) (Holm et al., 1969). Overgrowth of aquatic plants can also inhibit water movement and negatively impact flood control operations, thereby increasing the risk of catastrophic flooding of communities, farms, roadways, and other anthropocentric infrastructure during heavy rainfall events (Grant, 1962).

It is clear that invasive plants cause a wide variety of problems, but how are these species able to produce such large and troublesome populations? Exotic species can become weedy and exhibit aggressive growth in an invaded region for a number of reasons. Abiotic factors such as temperature, rainfall, and nutrient

\begin{tabular}{llll}
\hline $\begin{array}{l}\text { Units } \\
\begin{array}{l}\text { To convert U.S. to SI, } \\
\text { multiply by }\end{array}\end{array}$ & U.S. unit & SI unit & $\begin{array}{l}\text { To convert SI to U.S., } \\
\text { multiply by }\end{array}$ \\
\hline 0.4047 & acre(s) & ha & 2.4711 \\
0.3048 & $\mathrm{ft}$ & $\mathrm{m}$ & 3.2808 \\
3.7854 & gal & $\mathrm{L}$ & 0.2642 \\
2.54 & inch(es) & $\mathrm{cm}$ & 0.3937 \\
2.2417 & ton $(\mathrm{s}) / \mathrm{acre}$ & ${\mathrm{Mg} \cdot \mathrm{ha}^{-1}}^{-1}$ & 0.4461
\end{tabular}


availability may be more amenable in the invaded range compared to the native habitat of the species, thus fostering growth at levels not seen in the home territory of the invader. An important biotic factor that can result in explosive growth of a non-native species is the lack of specialist biological stressors in the introduced range. This phenomenon is often referred to as the "enemy release hypothesis," and it posits that phytopathogenic organisms (primarily fungi and bacteria) and phytophagous animals (e.g., insects) that have co-evolved with the species in question prevent aggressive growth of the plant in its native range. When a plant is introduced to a new ecosystem where these stressors are not present, they are "released" from the pressure imposed by these organisms and can experience unchecked growth in the invaded range (Keane and Crawley, 2002). This hypothesis forms the basis of classical biological control, which uses the introduction of co-evolved host-specific insects or pathogens as a means to manage invasive species. This strategy has been used with varying levels of success to reduce populations of a variety of noxious weeds, including waterhyacinth (Tipping et al., 2014), alligatorweed [Alternanthera philoxeriodes (Buckingham, 1996)], and air potato [Dioscorides bulbifera (Center et al., 2015)]. However, indigenous herbivores that are present in the invaded range are often polyphagous and feed indiscriminately on both native and exotic plants. In fact, Macel et al. (2017) suggested that exotic plants may be more susceptible to herbivory by phytophagous generalists in newly invaded regions compared to indigenous plants. Therefore, the release from herbivory is incomplete and invasion success is likely influenced by a combination of abiotic and biotic factors.

By definition, invasive species are introduced and not native to the ecosystem in which they become problematic (U.S. Department of Agriculture, 1999). However, it is becoming evident to resource managers that excessive growth of indigenous plants can cause similar ecosystem disruptions. The reasons for formerly well-behaved plants "going rogue" and overtaking formerly diverse areas are unclear, but several factors may contribute to these new growth patterns. For example, warmer average temperatures may facilitate range expansion by allowing plants to move into areas that have become newly hospitable (Upson et al., 2016). Extirpation or reduction of natural enemies may occur in response to changing environmental conditions, disease, predation, and intentional or inadvertent pest control operations. An important factor that seems to drive weedy behavior in native aquatic plants is what I term "competition release," or targeted management of introduced invasive species. Similar to the enemy release hypothesis, competition release frees native plants from competition with exotic species and allows them access to formerly unavailable resources such as light and nutrients. If the management techniques used do not include physical removal of the undesired plant material, then additional nutrient pulses are likely to occur as the dying plants decompose (Grimshaw, 2002; Jewell, 1971), which can further subsidize excessive growth by native plants.

The most intuitive way to address invasive behavior in native aquatic plants is to discuss them in the context of introduced exotic weeds with similar growth habits. The characteristics of representative floating, floating-leaved, submersed, and littoral (shoreline and shallow water) invaders are outlined and "weedy" native plants that are analogous to these exotic species are described in this work.

\section{Floating invasive exotic plant: water hyacinth}

Water hyacinth was introduced to Florida as an ornamental water garden plant in the 1880s. This South American native has water-repellant leaves with swollen petioles attached in a basal rosette; it bears large, showy, lavender flowers. Reports have indicated that it was intentionally released into the St. Johns River near Palatka, FL, because the introducer wanted to beautify the river (Buker, 1982). Within one decade, water hyacinth had spread throughout the system and rendered the waterway impassible. Because the St. Johns River was the major thoroughfare for transporting goods, produce, livestock, and people through Florida, the inability to navigate through dense mats of water hyacinth quickly became problematic. Although the U.S. Army Corps of Engineers was charged with clearing the system to facilitate navigation in 1899 , most control methods that were attempted were ineffective, were too expensive, or caused unacceptable off-target damage (e.g., cattle died after grazing water hyacinths treated with toxic substances such as sodium arsenate). The St. Johns River experienced navigation problems until the discovery of the synthetic herbicide 2,4-D, which was nontoxic to cattle and provided good control of water hyacinth (Gettys, 2014).

Growth of water hyacinth is checked only by temperature and nutrients, which are rarely limiting in the naturally warm and eutrophic waters of Florida. These floating weeds can quickly cover the surface of the water with dense mats of vegetation. Penfound and Earle (1948) reported that 8 months of growth would allow 10 water hyacinth plants to expand to a population of more than 655,000 plants, which would comprise more than 180 tons of biomass and cover a surface acre. Dense populations of water hyacinths and other floating plants hinder navigation, clog water control structures, block the air-water interface (which reduces dissolved oxygen needed by aquatic fauna), suppress light penetration (which reduces or eliminates submersed plant growth by inhibiting photosynthesis), and cause a variety of other problems. Due to its aggressive growth, water hyacinth is classified as a prohibited aquatic plant in Florida, and it is illegal to possess, collect, transport, cultivate, or import the species without a permit (Florida Department of State, 2008).

\section{Floating aggressive native plant: frog's bit (Limnobium spongia)}

The floating aquatic species frog's bit (also called american spongeplant) has a growth habit similar to that of water hyacinth. Although frog's bit is indigenous to North America, it routinely forms populations large enough to require management efforts (Les and Capers, 1999). For example, Bodle (1986) reported that frog's bit can have "water hyacinth-like growth"; as a result, the species is targeted for management 
in some aquatic ecosystems where it is native, including the often-invaded St. Johns River (Knight, 1985). The Florida Fish and Wildlife Conservation Commission (FWC), which is the state agency responsible for coordinating plant management in most of Florida's public waters, treated more than 900 acres of frog's bit between 2013 and 2018 (Florida Fish and Wildlife Conservation Commission, 2014, 2015, 2016, 2017, 2018). In addition to forming nuisance-level populations in its historic range, frog's bit is also expanding its range, with new introductions most likely due to seed transportation by ducks and other waterfowl and possibly escape from cultivation, because the species is sold as an aquarium plant (Anderson, 2011; Les and Mehrhoff, 1999).

\section{Floating-leaved invasive exotic plant: crested floatingheart}

Crested floatingheart has long been sold as an ornamental for water gardens, but it escaped cultivation in southwest Florida and was first found in a Collier County canal in the 1990s (Burks, 2002). This Asian native is undeniably beautiful; it bears cordate leaves (often with a deep red margin) and attractive white five-petal flowers. Crested floatingheart can grow in water as deep as $15 \mathrm{ft}$ and has long petioles that attach the leaves to the crown of the plant. There is little information regarding seed production in this species, but Haug (2018) found that leaf fragments readily produced adventitious roots and could serve as dispersive propagules. Most colonization and population expansion by this species result from the production of "ramets," which are vegetative structures that are produced near the junction of each petiole and leaf. Gettys et al. (2017) reported that single plants grown under nutrient-rich conditions produced more than 500 ramets over the course of a 6 -month culture period, and that $\approx 40 \%$ of unburied ramets would sprout. Using these data, Gettys et al. (2017) theorized that a single founder plant and its ramet-derived progeny could generate a population of 2.7 million plants after only 2 years of unchecked growth.

Crested floatingheart and other floating-leaved species cause habitat disruption by hindering navigation, clogging water control structures, blocking the air-water interface, and suppressing light penetration. Additionally, the dense underwater architecture created by the long petioles clogs the water column and interferes with flow, which makes it difficult to quickly move stormwater and increases the likelihood of flooding. Crested floatingheart and its congener yellow floatingheart (Nymphoides peltata) were added to the Florida Noxious Weed List in 2014; therefore, it is illegal to possess, collect, transport, cultivate, or import these species without a permit (Florida Department of State, 2014). Florida is suffering from crested floatingheart infestations, which have become firmly established; furthermore, crested floatingheart is considered a significant aquatic weed in South Carolina, where it was first reported in the wild in 2006 (Westbrook and McCord, 2010).

\section{Floating-leaved aggressive native plants: yellow waterlily (Nymphaea mexicana) and spatterdock [Nuphar lutea (synonym N. advena)]}

The floating-leaved aquatic species yellow waterlily (also called mexican waterlily) and spatterdock (also called cow-lily or yellow pondlily) have growth habits similar to that of crested floatingheart, although they are most often found in shallower water than crested floatingheart. Both species are native to North America and can develop large, dense populations that require management efforts to lessen negative impacts to anthropocentric and ecosystem services. For example, yellow waterlily was intentionally planted at Orlando Wetlands Park (Christmas, FL), which is a 1220 acre constructed wetland that processes as much as 35 million gallons of wastewater per day from the City of Orlando and surrounding communities (City of Orlando, n.d.). Approximately 2.3 million aquatic plants were used to vegetate the waters of the park, and yellow waterlily was included due to its native status and its ability to serve as a food source and refuge for ducks and other waterfowl. However, this species has greatly expanded its population size within the park, and the dense floating leaves prevent light penetration into the water column.
This suppresses the growth of submersed vegetation, which plays an important role in nutrient load reduction as water moves through the wetland (M. Sees, personal communication). Nuisance-level populations of yellow waterlily are not unique to Florida. For example, the USDA (n.d.) classifies the species as native to California, but it is also listed as a noxious weed in California (California Department of Food and Agriculture, n.d.).

Spatterdock, which has submersed, floating, and emergent leaves that are held as much as 8 inches above the surface of the water, usually colonizes areas where water depths are $6 \mathrm{ft}$ or less. The species is often included in aquatic restoration and habitat enhancement plans because it provides valuable ecosystem services such as creating fish habitats, stabilizing substrates, and mitigating nutrients (Slagle and Allen, 2018). Spatterdock has petioles that are much broader (diameter, up to 0.75 inches) than those of yellow waterlily or crested floatingheart (diameter, 0.25 inches); these petioles, along with the submersed leaves (Schoelynck et al., 2014), can cause substantial water flow attenuation in shallow systems. Wennerberg (2004) reported that the species "...may become weedy in some regions or habitats and may displace desirable vegetation if not properly managed." Haberland (2016) echoed this sentiment and stated that spatterdock's rapid growth in nutrient-rich waterbodies could result in complete surface coverage in a few years. For example, the FWC treated more than 1600 acres of spatterdock between 2013 and 2018 (Florida Fish and Wildlife Conservation Commission, 2014, 2015, 2016, 2017, 2018).

\section{Submersed invasive exotic plant: hydrilla}

There are two biotypes of hydrilla: monoecious (plants bearing separate pistillate and staminate flowers on the same plant) and dioecious (plants bearing either pistillate or staminate flowers). The monoecious biotype, which is thought to be a Korean native (Madeira et al., 1997), prefers temperate climates and is mostly found in North Carolina and northward in the United States (True-Meadows et al., 
2016), although it is occasionally found as far south as Georgia. Its introduction history is uncertain, but Haller (1982) reported finding hydrilla (later identified as the monoecious type) in containerized water garden plants in a concrete-lined lake in Washington, DC, in 1980. A visit to the source nursery revealed that hydrilla was present throughout the nursery stock and was likely misidentified as american elodea (Elodea canadensis) or the exotic (but not particularly invasive) anacharis (Egeria densa) (Haller, 1982). The dioecious biotype, which is native to India (Madeira et al., 1997), occurs predominantly in tropical regions and is the biotype present in Florida. Dioecious hydrilla was introduced to Florida as an oxygenator for aquariums in the late $1950 \mathrm{~s}$ (McLane, 1969) and quickly escaped cultivation. When the plant was first found in the wild in 1960 , it was also misidentified as american elodea (Blackburn et al., 1969). By the time hydrilla was correctly identified as an introduced species, it had invaded many thousands of acres of Florida's waters (Gettys and Enloe, 2016).

The biotypes of hydrilla are phenotypically similar because both have small $(0.75$ inches long $\times 0.20$ inches wide) lanceolate leaves with serrate margins that are attached in a whorl of four to eight leaves per node. They can colonize water as deep as $20 \mathrm{ft}$ and reproduce mainly by fragmentation, although both species produce tubers and turions-vegetative structures that are produced in the soil and the leaf axils, respectively-that comprise a propagule bank and allow populations to regenerate after catastrophic events such as herbicide treatments, desiccation, or freezing temperatures. In contrast, the phenology of the biotypes differs in substantial ways (i.e., sexual reproduction, tuber production, and winter behavior). The monoecious biotype produces seeds and the dioecious biotype does not, although the dioecious biotype has been shown to be fully fertile after artificial pollinations, and its lack of fecundity in its invaded range is due to the absence of a pollen source as opposed to inherent fertility issues (Steward, 1993). Van (1989) found that tuber production by the monoecious biotype was greater than that by the dioecious biotype under both long and short days (16 and $10 \mathrm{~h}$ of light, respectively). Furthermore, the dioecious biotype only produced tubers after 8 weeks of culture under short-day conditions (compared with 4 weeks for the monoecious biotype), and it produced no tubers under long-day conditions. Van (1989) also reported that vegetative growth of the dioecious biotype was greater than that of the monoecious biotype under long-day conditions. Finally, the monoecious biotype of hydrilla is deciduous in its invaded range, whereas the dioecious biotype is evergreen and persists throughout the year in the warmer waters of the southern United States (Harlan et al., 1985).

Similar to floating and floatingleaved plants, submersed weeds such as hydrilla hinder navigation, clog water control structures, block the air-water interface, and suppress light penetration. This is especially true of canopy-forming submersed species. For example, Haller and Sutton (1975) reported that approximately half of all hydrilla biomass occurred in the upper 18 inches of the water column, with $20 \%$ of the total biomass of hydrilla concentrated in the upper 6 inches; they found no light penetration at depths greater than 1 $\mathrm{ft}$. Dense growth of submersed plants can also interfere with recreational activities and pose threats to human health. There have been multiple reports of swimmers drowning after becoming entangled in hydrilla, including the researcher responsible for the correct identification of hydrilla in 1965, who later died during a diving mishap while scouting for sites to conduct submersed weed research (Weeds Trees and Turf, 1970).

\section{Submersed aggressive native plants: eelgrass (Vallisneria americana) and illinois pondweed (Potamogeton illinoinensis)}

Eelgrass and illinois pondweed are native to North America. Like hydrilla, they require submersed conditions to survive. Both species provide valuable ecosystem services and are frequently included in freshwater enhancement and restoration projects. In addition to stabilizing substrates and removing nutrients from the water column, these plants provide food and habitats for aquatic fauna (Carpenter and Lodge, 1986; Fleming et al., 2011). Successful establishment of submersed species can be inhibited by abiotic factors such as currents and unsuitable nutrient levels; however, because species such as eelgrass provide such important ecosystem services, methods have been developed to improve field establishment and identify widely adapted ecotypes that tolerate adverse environmental conditions (Gettys and Haller, 2012, 2013).

The growth habit of eelgrass is quite different from hydrilla, although both are Hydrocharitaceae. Eelgrass has a rosette growth form, with long (up to $6 \mathrm{ft}$ ), strap-like, sessile leaves attached at the base of the plant, whereas hydrilla is a branched, clump-forming species with many stems that bear small leaves in a verticillate arrangement. Eelgrass is dioecious, and both plant types (pistillate-bearing and staminatebearing) are typically present in most populations. Pistillate flowers float on the surface of the water and are supported by long (up to $6.5 \mathrm{ft}$ ) peduncles, whereas staminate flowers are borne in a capsule at the base of the plant before they are released and allowed to float to the water's surface (Godfrey and Wooten, 1979). The species is fertile and does reproduce via seeds, but most population expansion occurs as a result of vegetative reproduction (i.e., daughter plants or ramets produced on subterranean rhizomatous runners). Eelgrass is an important component of healthy ecosystems (Jaggers, 1994), but it can easily form nuisance-level populations that require management, particularly in human-made settings such as community lakes, reservoirs, and golf course ponds. Most problems associated with the overgrowth of eelgrass are aesthetic; the plant routinely sheds leaves, which results in unattractive, unkempt shorelines as leaves accumulate along the water's margins. The long peduncles bearing pistillate flowers can become entangled in fishing gear, outboard motors, and other watercraft, which can be an annoyance to anglers and others who use eelgrass-rich areas for recreational purposes.

Illinois pondweed has a growth habit that is more similar to that of 
hydrilla; however, illinois pondweed occasionally produces floating leaves as well as submersed leaves. The submersed leaves of illinois pondweed are much larger (up to 3 inches long $x$ 0.75 inches wide) than those of hydrilla $(0.75$ inches long $\times 0.20$ inches wide) and are arranged in an alternate manner on long, slender stems (DiTomaso and Healy, 2003). Illinois pondweed grows in waters as deep as $20 \mathrm{ft}$ and reproduces via sexual and asexual means. The starchy seeds are an excellent food source for ducks and other waterfowl, and they can remain viable for up to 5 years. Like hydrilla, dense populations of illinois pondweed can degrade ecosystems and habitats by blocking the air-water interface and suppressing light penetration. Furthermore, it can interfere with anthropocentric activities by hindering navigation, clogging water control structures, and disrupting recreational activities. To mitigate the negative effects of dense pondweed growth, the FWC treated more than 1840 acres of pondweed between 2013 and 2018, with the majority of that acreage treated in two lakes during fiscal year 2013-14 (1350 acres in East Lake Tohopekeliga and 275 acres in Lake June-In-Winter) (Florida Fish and Wildlife Conservation Commission, 2014, 2015, 2016, 2017, 2018).

\section{Littoral exotic invasive plant: torpedograss (Panicum repens)}

Torpedograss is a perennial grass of Old-World origin (Holm et al., 1977) that was introduced to the southeastern United States as a potential forage crop. Although its introduction history is unclear, torpedograss has been in the United States for several centuries. It was vouchered in Alabama in 1876, and it was first introduced to Florida as a potential forage crop in the 1900s (Overholt and Franck, 2017; Tarver, 1979). The species was intentionally planted throughout southern Florida (and in some parts of central and northern Florida); by the 1950s, it had escaped cultivation and invaded pastures, wetlands, and aquatic systems (Langeland et al., 1998). Torpedograss is not listed as a noxious weed by the United States or the state of Florida, but the Florida Exotic Pest Plant
Council, a nonregulatory group comprising biologists, resource managers, and other interested individuals, lists the species as a category I exotic plant. Plants in this group are characterized as "...altering native plant communities by displacing native species, changing community structures or ecological functions, or hybridizing with natives" (Florida Exotic Pest Plant Council, 2017).

Torpedograss is a rhizomatous grass that is commonly found along shorelines and in littoral areas of lakes, ponds, reservoirs, canals, and other aquatic systems where water is up to 2 ft deep (Godfrey and Wooten, 1979), although it often invades upland areas such as pastures and turfgrass. The rhizome tips are pointed and extremely sharp (hence the "torpedo" part of its common name). Viable seed production is not known to occur in Florida; therefore, reproduction, population expansion, and spread of the species occur primarily through fragmentation and rhizome elongation (Holm et al., 1977). The rhizomes and stolons of torpedograss have overlapping brown to white scales and bulbil-like structures at the nodes and may extend up to 20 $\mathrm{ft}$ from the crown of the plant, facilitating population expansion. Plants may reach up to $3 \mathrm{ft}$ in height and bear 0.3 -inch-wide leaves that are up to 10 inches in length. The surface of the leaf blade is waxy, which sometimes gives the leaves a dusky or blue cast; the leaf margin and the clasping ligule that holds the leaf to the stem are often hairy. The inflorescence is a terminal open panicle that is up to 9 inches long (Langeland et al., 1998).

Some of the problems associated with littoral zone weeds such as torpedograss are similar to those described for floating, floating-leaved, and submersed species. Dense populations can hinder navigation (especially in near-shore areas), clog water-control structures, disrupt the movement of stormwater, and interfere with recreational activities. Although torpedograss is rooted in the littoral zone, the species often forms dense floating mats that extend across the surface of the water, thus blocking light and oxygen penetration in a manner similar to that of water hyacinth, crested floatingheart, and canopy-forming hydrilla. Torpedograss also outcompetes most native littoral zone species, resulting in monocultures that provide poor habitats for aquatic fauna (Shilling and Haller, 1989).

\section{Littoral aggressive native plants: pickerelweed (Pontederia cordata), broadleaf arrowhead (Sagittaria latifolia), and lanceleaf arrowhead (Sagittaria lancifolia)}

Pickerelweed, broadleaf arrowhead, and lanceleaf arrowhead are native to North America; like torpedograss, they inhabit shorelines and littoral regions of aquatic systems. Similar to the native submersed plants eelgrass and illinois pondweed, these three species are often planted in freshwater enhancement and restoration projects because they provide valuable ecosystem services such as substrate stabilization and nutrient removal while providing food and habitats for aquatic fauna. Resource managers attempting to implement restoration projects often find that there is a dearth of acceptable plant material available to meet their goals; therefore, research to identify greenhouse-based production methods for these and other littoral zone species has been conducted (Dick et al., 2005; Flimlin and Pomeroy, 2008; Gettys and Moore, 2018, 2019; Gettys et al., 2001, 2013; Webb et al., 2012). In addition to the benefits these species provide to the environment, pickerelweed, broadleaf arrowhead, and lanceleaf arrowhead are also cultivated as ornamentals for water gardens and aquascapes.

Pickerelweed, broadleaf arrowhead, and lanceleaf arrowhead are similar to one another in a number of ways. All are herbaceous perennials that readily produce seeds, but they also spread by vegetative means. Similar to torpedograss, these species inhabit the littoral shoreline zone of aquatic systems and can grow in water as deep as $2 \mathrm{ft}$. Pickerelweed has smooth-margined leaves that are up to 8 inches long and range in shape from lanceolate to cordate, whereas broadleaf arrowhead and lanceleaf arrowhead leaves are up to $\mathrm{lft}$ in length and sagittate (broadleaf arrowhead) or up to $2 \mathrm{ft}$ long and lanceolate (lanceleaf arrowhead). The inflorescence of pickerelweed is a spike comprising up to 400 purple to blue (or 
rarely white) sessile flowers, each with a yellow "eyespot" ringed in white (Gettys, 2005). Broadleaf arrowhead and lanceleaf arrowhead have white three-petal pedicellate flowers with a yellow center that are borne singly or in clusters on long peduncles (Moore et al., 2015). These three species are beneficial in many situations; however, under the right circumstances they can develop nuisance-level populations and cause problems similar to those described for torpedograss. They disrupt the movement of stormwater and interfere with recreational activities, particularly by blocking access to boat ramps and other points of entry to a water resource. Pickerelweed, broadleaf arrowhead, and lanceleaf arrowhead do not form floating mats, but they can be highly competitive and crowd other littoral zone species, thus creating monocultures that serve as poor habitats for aquatic fauna.

\section{Conclusions}

Non-native plants can threaten ecosystems by outcompeting native plants, reducing species richness, altering abiotic factors, and interfering with anthropocentric interests such as crop production. Aquatic ecosystems are especially vulnerable to invasion by exotic plants that have exuberant growth and can create risks to human health, clog irrigation intakes, interfere with recreation, and inhibit water movement. It is widely accepted that introduced species pose significant risks when they invade our waters, but little thought has been given to the phenomenon of native species that sometimes grow excessively and form nuisance-level populations that can cause the same disruptions historically associated with non-native plants. Several factors may contribute to aggressive growth of native species, including climate change, altered abiotic factors, and competition release resulting from targeted management of introduced invasive species. Although most management efforts focus on invasive exotic plants such as water hyacinth, crested floatingheart, hydrilla, and torpedograss, it is clear that aquatic resource managers should be poised to face new challenges from "natives gone rogue" as our weed populations shift from exclusively invasive non-native species to include aggressive indigenous plants.

\section{Literature cited}

Anderson, L. 2011. Spongeplant: A new aquatic weed threat in the Delta. Cal-IPC News 19(1):4-5.

Blackburn, R.D., L.W. Weldon, R.R. Yeo, and T.M. Taylor. 1969. Identification and distribution of certain similar-appearing aquatic weeds in Florida. Hyacinth Control J. 8:17-21.

Bodle, M.J. 1986. American frog's bit. Aquatics 8(3):4-6.

Bridges, D.C. 1994. Impact of weeds on human endeavors. Weed Technol. 8(2):392-395.

Brooks, M.L., C.M. D'Antonio, D.M. Richardson, J.B. Grace, J.E. Keeley, J.M. DiTomaso, R.J. Hobbs, M. Pellant, and D. Pyke. 2004. Effects of invasive alien plants on fire regimes. Bioscience 54(7):677-688.

Buckingham, G.R. 1996. Biological control of alligatorweed, Alternanthera philoxeroides, the world's first aquatic weed success story. Castanea 61(3):232-243.

Buker, G.E. 1982. Engineers vs. Florida's green menace. Florida Historical Qrtly. 60(4):413-427.

Burks, K.C. 2002. Nymphoides cristata (Roxb.) Kuntze, a recent adventive expanding as a pest plant in Florida. Castanea 67(2):206-211.

California Department of Food and Agriculture. n.d. California noxious weeds: Mexican waterlily or banana waterlily [Nymphaea mexicana Zucc.]. 30 Jan. 2019. <https://www.cdfa.ca.gov/ plant/IPC/encycloweedia/weedinfo/ nymphaea.htm $>$.

Carpenter, S.R. and D.M. Lodge. 1986. Effects of submersed macrophytes on ecosystem processes. Aquat. Bot. 26:341370 .

Center, T.D., W.A. Overholt, E. Rohrig, and M. Rayamajhi. 2015. Classical biological control of air potato in Florida. Univ. Florida, Inst. Food Agr. Sci., IFAS Publ. ENY-864. 16 Jan. 2019. <https:// edis.ifas.ufl.edu/pdffiles/IN/IN95700. pdf $>$.

City of Orlando. n.d. Orlando Wetlands Park: History. 30 Jan. 2019. <http:// www.cityoforlando.net/wetlands/ history $/>$.

Cuda, J.P. 2014. Aquatic plants, mosquitoes and public health, p. 31-36. In: L.A. Gettys, W.T. Haller, and D.G. Perry (eds.). Biology and control of aquatic plants: A best management practices handbook. 3rd ed. Aquatic Ecosystem Restoration Foundation, Marietta, GA.
Dibble, E.D., K.J. Killgore, and S.L. Harrel. 1996. Assessment of fish-plant interactions. Multidimensional approaches to reservoir fisheries management. Amer. Fish. Soc. Symp. 16:357-372.

Dick, G.O., R.M. Smart, and J.R. Snow. 2005. Propagation and production of native aquatic plants. ERDC/TN APCRP-EA-11. U.S. Army Eng. Res. Dev. Ctr., Omaha, NE.

DiTomaso, J.M. and E.A. Healy. 2003. Aquatic and riparian weeds of the West. Univ. California Agr. Natural Resources, CANR Publ. 3420.

Duryea, M.L. and E. Kampf. 2017. Wind and trees: Lessons learned from hurricanes. Univ. Florida, Inst. Food Agr. Sci., IFAS Publ. FOR 118. 16 Jan. 2019. <https://edis.ifas.ufl.edu/pdffiles/FR/ FR17300.pdf>.

Fleming, J.P., J.D. Madsen, and E.D. Dibble. 2011. Macrophyte re-establishment for fish habitat in Little Bear Creek Reservoir, Alabama, USA. J. Freshwat. Ecol. 26(1):105114.

Flimlin, G. and R. Pomeroy. 2008. Growing ornamental aquatic plants as a business in the northeastern United States. Northeastern Reg. Aquacult. Ctr., College Park, MD.

Florida Department of State. 2008. Rule chapter 5B-64: Aquatic plant importation, transportation, non-nursery cultivation, possession and collection. 22 Jan. 2019. <https://www.flrules.org/gateway/ ChapterHome.asp? Chapter $=5 \mathrm{~B}-64>$.

Florida Department of State. 2014. Rule chapter 5B-57.007: Introduction or release of plant pests, noxious weeds, arthropods, and biological control agents. 22 Jan. 2019. <https://www.flrules.org/gateway/ ChapterHome.asp? Chapter $=5 \mathrm{~B}-57>$.

Florida Exotic Pest Plant Council. 2017. Florida Exotic Pest Plant Council 2017 list of invasive plant species. 12 Feb. 2019. <http://bugwoodcloud.org/CDN/fleppc/ plantlists /2017/2017FLEPPCLISTTRIFOLD-FINALAPPROVEDBYKENSUBMITTEDTOALTA.pdf>.

Florida Fish and Wildlife Conservation Commission. 2014. Florida Fish and Wildlife Conservation Commission annual report of activities conducted under the Cooperative Aquatic Plant Control Program in Florida public waters for fiscal year 2013-2014. 25 Feb. 2019. <https://myfwc.com/media/3200/ aquaticplantmanagement-2013-2014. pdf $>$.

Florida Fish and Wildlife Conservation Commission. 2015. Florida Fish and Wildlife Conservation Commission annual report of activities conducted under 
the Cooperative Aquatic Plant Control Program in Florida public waters for fiscal year 2014-2015. 25 Feb. 2019. <https://myfwc.com/media/3201/ aquaticplantmanagement-fyl4-15.pdf $>$.

Florida Fish and Wildlife Conservation Commission. 2016. Florida Fish and Wildlife Conservation Commission annual report of activities conducted under the Cooperative Aquatic Plant Control Program in Florida public waters for fiscal year 2015-2016. 25 Feb. 2019. <https://myfwc.com/media/ 3193/annualreport15-16.pdf>.

Florida Fish and Wildlife Conservation Commission. 2017. Florida Fish and Wildlife Conservation Commission annual report of activities conducted under the Cooperative Aquatic Plant Control Program in Florida public waters for fiscal year 2016-2017. 25 Feb. 2019. <https://myfwc.com/media/ 3194/annualreport16-17.pdf>.

Florida Fish and Wildlife Conservation Commission. 2018. Florida Fish and Wildlife Conservation Commission annual report of activities conducted under the Cooperative Aquatic Plant Control Program in Florida public waters for fiscal year 2017-2018. 25 Feb. 2019. <https://myfwc.com/media/ 19112/annualreport17-18.pdf>.

Gettys, L.A. 2005. Inheritance of morphological characters of pickerelweed (Pontederia cordata L.). PhD Diss., Univ. Florida, Gainesville. 15 Feb. $2019<$ http://etd.fcla. edu/UF/UFE0009585/gettys_l.pdf>.

Gettys, L.A. 2014. Waterhyacinth: Florida's worst floating weed. Univ. Florida, Inst. Food Agr. Sci., IFAS Publ. SS-AGR380. 15 Jan. 2019. <https://edis.ifas.ufl. edu/ag385>.

Gettys, L.A., C.J. Della Torre, K.M. Thayer, and I.J. Markovich. 2017. Asexual reproduction and ramet sprouting of crested floatingheart (Nymphoides cristata). J. Aquat. Plant Mgt. 55:83-88.

Gettys, L.A. and S.F. Enloe. 2016. Hydrilla: Florida's worst submersed weed. Univ. Florida, Inst. Food Agr. Sci., IFAS Publ. SSAGR-444. 15 Jan. 2019. <http://edis.ifas. ufl.edu/pdffiles/AG/AG40400.pdf>.

Gettys, L.A. and W.T. Haller. 2012. Greenhouse culture of submersed aquatic vegetation "sod". Proc. Florida State Hort. Soc. 125:386-389.

Gettys, L.A. and W.T. Haller. 2013. Effect of ecotype, sediment composition, and fertility level on productivity of eight Florida ecotypes of american eelgrass (Vallisneria americana). J. Aquat. Plant Mgt. 51:127-131.
Gettys, L.A. and K.A. Moore. 2018. Greenhouse culture and production of four ornamental native wetland plants. Hort Technology 28:332-336.

Gettys, L.A. and K.A. Moore. 2019. Greenhouse production of native aquatic plants. HortTechnology 29:41-45.

Gettys, L.A., K.A. Moore, and W. Orozco Obando. 2013. Effect of sediment type and fertility level on growth of swamp rosemallow (Hibiscus grandiflorus Michx.). Proc. Florida State Hort. Soc. 126:321-324.

Gettys, L.A., S.J. Peters, and D.L. Sutton. 2001. Culture and production of pickerelweed using three different substrates. Proc. Florida State Hort. Soc. 114:252254.

Godfrey, R.K. and J.W. Wooten. 1979. Aquatic and wetland plants of southeastern United States: Monocotyledons. Univ. Georgia Press, Athens, GA.

Grant, Z.C. 1962. Aquatic weed control program of the Central and Southern Florida Flood Control District. Hyacinth Control J. 1:24-30.

Grimshaw, H.J. 2002. Nutrient release and detritus production by herbicidetreated freely floating aquatic vegetation in a large, shallow subtropical lake and river. Arch. Hydrobiol. 153(3):469490.

Haberland, M. 2016. Ecology and control of the freshwater aquatic plant spatterdock (Nuphar sp.). Rutgers Univ., New Jersey Agr. Expt. Sta., Coop. Ext. Fact Sheet FS1255. 30 Jan. 2019. $<$ https://njaes.rutgers.edu/fs1255/>.

Haller, W.T. 1982. Hydrilla goes to Washington. Aquatics 4(4):6-8.

Haller, W.T. and D.L. Sutton. 1975. Community structure and competition between hydrilla and vallisneria. Hyacinth Control J. 13:48-50.

Harlan, S.M., G.J. Davis, and G.J. Pesacreta. 1985. Hydrilla in three North Carolina lakes. J. Aquat. Plant Mgt. 23:68-71.

Haug, E.J. 2018. Monoecious hydrilla and crested floating heart biology, and the response of aquatic plant species to florpyrauxifen-benzyl herbicide. PhD Diss., North Carolina State Univ., Raleigh. 26 Jan. 2019. <https://repository.lib.ncsu. edu/bitstream/handle/1840.20/ 35124/etd.pdf?sequence $=1>$.

Holm, L.G., D.L. Plucknett, J.V. Pancho, and J.P. Herberger. 1977. The world's worst weeds: Distribution and biology. Univ. Press of Hawaii, Honolulu, HI.
Holm, L.G., L.W. Weldon, and R.D. Blackburn. 1969. Aquatic weeds. Science 166(3906):699-709.

Jaggers, B.V. 1994. Vallisneria americana: Considerations for restoration in Florida. Florida Game and Fresh Water Fish Commission, Eustis, FL.

Jeppesen, E., M. Sondergaard, M. Sondergaard, and K. Christoffersen (eds.). 1998. The structuring role of submerged macrophytes in lakes. Springer-Verlag, New York, NY.

Jewell, W.J. 1971. Aquatic weed decay: Dissolved oxygen utilization and nitrogen and phosphorus regeneration. Water Pollution Control Federation J. 43(7):1457-1467.

Keane, R.M. and M.J. Crawley. 2002. Exotic plant invasions and the enemy release hypothesis. Trends Ecol. Evol. 17(4):164-170.

Knight, E.D. 1985. Control of frog's bit. Aquatics 7(1):24.

Langeland, K., B. Smith, and C. Hanlon. 1998. Torpedograss - Forage gone wild. Wildland Weeds 1(3):4-6.

Les, D.H. and R.S. Capers. 1999. Limnobium spongia (Hydrocharitaceae) discovered in New England. Rhodora 101:419-423.

Les, D.S. and L.J. Mehrhoff. 1999. Introduction of nonindigenous aquatic vascular plants in southern New England: A historical perspective. Biol. Invasions 1:281-300.

Macel, M., T. Dostálek, S. Esch, A. Bucharová, N.M. van Dam, K. Tielbörger, K.J.F. Verhoeven, and Z. Münzbergová. 2017. Evolutionary responses to climate change in a range expanding plant. Oecologia 184(2):543-554.

Madeira, P., T. Van, D. Steward, and R. Schnell. 1997. Random amplified polymorphic DNA analysis of the phenetic relationships among world-wide accessions of Hydrilla verticillata. Aquat. Bot. 59:217-236.

Madsen, J.D. 2014. Impact of invasive aquatic plants on aquatic biology, p. 111. In: L.A. Gettys, W.T. Haller, and D.G. Perry (eds.). Biology and control of aquatic plants: A best management practices handbook. 3rd ed. Aquatic Ecosystem Restoration Foundation, Marietta, GA.

McLane, W.M. 1969. The aquatic plant business in relation to infestations of exotic aquatic plants in Florida waters. Hyacinth Control J. 8:48-49.

Moore, K.A., L.E. Fisher, C.J. Della Torre, III, and L.A. Gettys. 2015. Native 
aquatic and wetland plants: Duck potato, Sagittaria lancifolia. Univ. Florida, Inst. Food Agr. Sci., IFAS Publ. SS-AGR-399. 15 Jan. 2019. <https://edis.ifas.ufl.edu/ ag403>.

Overholt, W.A. and A.R. Franck. 2017. The invasive legacy of forage grass introductions into Florida. Nat. Areas J. 37(2):254-264.

Penfound, W.T. and T.T. Earle. 1948. The biology of the water hyacinth. Ecol. Monogr. 18(4):447-472.

Rao, A.N., D.E. Johnson, B. Sivaprasad, J.K. Ladha, and A.M. Mortimer. 2007. Weed management in direct-seeded rice. Adv. Agron. 93:153-255.

Schoelynck, J., K. Bal, V. Verschoren, E. Penning, E. Struyf, T. Bouma, D. Meire, P. Meire, and S. Temmerman. 2014. Different morphology of Nuphar lutea in two contrasting aquatic environments and its effect on ecosystem engineering. Earth Surf. Process. Landf. 39(15):2100-2108.

Shilling, D.G. and W.T. Haller. 1989. Interactive effects of diluent $\mathrm{pH}$ and calcium content on glyphosate activity on Panicum repens L. (torpedograss). Weed Res. 29(6):441-448.

Slagle, Z.J. and M.S. Allen. 2018. Should we plant macrophytes? Restored habitat use by the fish community of Lake
Apopka, Florida. Lake Reserv. Mgt. 34(3):296-305.

Steward, K.K. 1993. Seed production in monoecious and dioecious populations of Hydrilla. Aquat. Bot. 46(2):169-183.

Tarver, D.P. 1979. Torpedograss (Panicum repens L.). Aquatics 1(2):5-6.

Tipping, P.W., M.R. Martin, E.N. Pokorny, K.R. Nimmo, D.L. Fitzgerald, F.A. Dray, Jr., and T.D. Center. 2014. Current levels of suppression of waterhyacinth in Florida USA by classical biological control agents. Biol. Control 71:65-69.

True-Meadows, S., E.J. Haug, and R.J. Richardson. 2016. Monoecious hydrilla A review of the literature. J. Aquat. Plant Mgt. 54:1-11.

Upson, R., J.J. Williams, T.P. Wilkinson, C.P. Clubbe, I.M.D. Maclean, J.H. McAdam, and J.F. Moat. 2016. Potential impacts of climate change on native plant distributions in the Falkland Islands. PLoS One 11(11):e0167026, doi: 10.1371/journal.pone.0167026.

U.S. Department of Agriculture. 1999. Executive orders for invasive species: Executive Order 13112. 25 Feb. 2019. <https:// www.invasivespeciesinfo.gov/executiveorder-13112-section-1-definitions>.
U.S. Department of Agriculture. n.d. Natural Resources Conservation Service PLANTS database: Nymphaea mexicana Zucc. 25 Jan. 2019. <https://plants.usda. gov/core/profile? symbol=NYME $>$.

Van, T.K. 1989. Differential responses to photoperiods in monoecious and dioecious Hydrilla verticillata. Weed Sci. 37(4):552-556.

Webb, M.A., R.A. Ott, Jr., C.C. Bonds, R.M. Smart, G.O. Dick, and L. Dodd. 2012. Propagation and establishment of native aquatic plants in reservoirs (Data Series No. 273). Texas Parks and Wildlife Department Inland Fisheries Division, Austin, TX.

Weeds Trees and Turf. 1970. Aquatic weed researcher Dr. Lyle Weldon drowns. Weeds Trees Turf 9(3):49. 31 Jan. 2019. $<$ http://archive.lib.msu.edu/tic/wetrt/ article/1970mar.pdf>.

Wennerberg, S. 2004. United States Department of Agriculture Natural Resources Conservation Service plant guide: Yellow pond-lily (Nuphar lutea) (L.) Sm. 15 Jan. 2019. <https://plants.usda.gov/ plantguide/pdf/pg_nulu.pdf $>$.

Westbrook, R.G. and L. McCord. 2010. EDRR fact sheet: Crested floating heart. 30 Jan. 2019. <http://nceppc.weebly.com/ uploads $/ 6 / 8 / 4 / 6 / 6846349 /$ crested_ floating_heart.pdf $>$. 